\title{
KETIMPANGAN PEMBANGUNAN WILAYAH DI PROVINSI KALIMANTAN TENGAH (KAJIAN PADA KABUPATEN KOTAWARINGIN TIMUR DAN PEMEKARANNYA)
}

\author{
Inequality of Regional Development in Central Kalimantan Province, \\ Study in Kotawaringin Timur Region and developing area.
}

\section{Luthfian Riza Sanjaya ${ }^{1}$, Endriatmo Soetarto ${ }^{2}$ and Andrea Emma Pravitasari ${ }^{3}$}

Diterima: 18 Desember 2017 Disetujui: 17 Agustus 2018

\begin{abstract}
Abstrak: Ketimpangan pembangunan wilayah adalah masalah umum yang dihadapi oleh semua provinsi di Indonesia, tidak terkecuali Provinsi Kalimantan Tengah. Ketimpangan wilayah bersumber dari faktor - faktor yang seharusnya bisa diminimalisir. Tujuan penelitian ini antara lain 1) menganalisis trend ketimpangan pembangunan regional di provinsi Kalteng dan faktor yang mempengaruhinya 2) menganalisis hirarki perkembangan wilayah di Kabupaten Kotawaringin Timur (Kotim) dan pemekarannya 3) menganalisis ketimpangan pembangunan pada Kabupaten Kotawaringin Timur dan pemekarannya serta faktor yang berpengaruh menggunakan Geographical Weighted Regression (GWR), 4) menyusun rencana arahan dan kebijakan pengembangan wilayah. Metode yang digunakan yaitu Indek Williamson, Regresi Berganda dengan Unbalanced Panel, Skalogram berbobot dan GWR. Hasil penelitian ini menunjukan bahwa tingkat ketimpangan pembangunan wilayah di Provinsi Kalteng cenderung menurun dengan RHGU sebagai faktor yang paling dominan diantara faktor lain. Perkembangan wilayah di level kecamatan menunjukan fluktuasi namun cenderung tetap dengan pola spasial menunjukkan adanya ketimpangan antara wilayah utara dan selatan. Hasil GWR juga menunjukkan RHGU masih menjadi faktor dominan dengan pengaruh yang sama diseluruh wilayah penelitian. Dengan demikian, urgensi reforma agraria di kawasan perkebunan penting untuk segera dilaksanakan.
\end{abstract}

\section{Kata kunci: Ketimpangan, HGU dan GWR}

Abstract: Inequality of regional development is a common problem faced by all provinces in Indonesia, not least the Province of Central Kalimantan. Regional inequality stems from factors that should be minimized. The aims of this research were 1)to tanalyze the trend of regional development inequality in Central Kalimantan Province and the factors that influence it 2) to analyze the hierarchy of regional development in Kotawaringin Timur (Kotim) Regency and developing area 3) to analyze regional development inequality and influenced factors using Geographical Weighted Regression (GWR).4) to prepare regional directives and policy development plans. The method used are Williamson's Index, Multiple Regression with

\footnotetext{
${ }^{1}$ Program Studi Ilmu Perencanaan Wilayah, Sekolah Pascasarjana IPB

2 Departemen Sains Komunikasi dan Pengembangan Masyarakat

${ }^{3}$ Departemen Ilmu Tanah dan Sumber Daya Lahan
} 
Unbalanced Panel, weighted Skalogram, and GWR. The results of this study indicated that the level of inequality in Central Kalimantan Province tends to decrease with RHGU as the most dominant factor. The regional development of the area at the sub-district level showed spatial patterns which indicated an imbalance between the northern and southern regions. The GWR resulted also shows that RHGU is still the dominant factor with the same influence throughout the research area. Thus, the urgency of agrarian reform in plantation areas is important to be implemented immediately.

Keywords: Inequality, $H G U, G W R$

\section{PENDAHULUAN}

Ketimpangan pembangunan wilayah seringkali menjadi permasalahan yang serius karena berimplikasi terhadap kelancaran proses pembangunan. Beberapa daerah mencapai pertumbuhan yang signifikan, sementara beberapa daerah lainnya mengalami pertumbuhan yang lambat. Menurut Tambunan (2003) ketimpangan pembangunan wilayah bisa disebabkan oleh banyak faktor antara lain pusat kegiatan ekonomi, perbedaan sumberdaya, aksesibilitas, kondisi demografis dan alokasi investasi. Mohiuddin dan Hashia (2012) juga menambahkan faktor struktur institusi dan diskriminasi kebijakan sebagai faktor penyebab ketimpangan wilayah. Oleh karena itu, tidaklah mengherankan apabila disetiap daerah ditemukan wilayah yang maju dan wilayah terbelakang sebagaimana yang terjadi di Provinsi Kalimantan Tengah.

Provinsi Kalimantan Tengah secara administrasi terdiri dari 13 kabupaten dan 1 kota dengan kondisi pertumbuhan ekonomi yang beragam antar kabupaten/kota. Secara keseluruhan pertumbuhan ekonomi antar kabupaten/ kota di Provinsi Kalimantan Tengah tidak terlalu tinggi. Pertumbuhan ekonomi hanya terpusat pada kabupaten induk yang memiliki sarana - prasarana pendukung relatif lebih baik dibandingkan kabupaten pemekaran. Menurut data BPS (2016) Provinsi Kalimantan Tengah memiliki luas wilayah terbesar kedua di Indonesia setelah Provinsi Papua dengan luas 157,504.72 km2 dengan laju pertumbuhan PDRB tertinggi se-Pulau Kalimantan dan lebih tinggi $1.34 \%$ dari pertumbuhan ekonomi nasional. Potensi wilayah tersebut begitu besar namun sayangnya pemerataan infrastukuktur dan pembangunan aksesibilitas antar wilayah kota dan kabupaten masih belum maksimal sehingga pencapaian pemerataan pembangunan juga belum optimal. Pemerataan kesejahteraan dianggap sebagai salah satu bentuk operasional keadilan sosial yang juga merupakan tujuan hakiki pembangunan (Rustiadi et al. 2011). Dengan kata lain, ada indikasi ketimpangan pembangunan di Provinsi Kalimantan Tengah dimana proses pembangunan wilayah lebih terfokus pada wilayah kabupaten induk yang memiliki pusat - pusat pertumbuhan. Kabupaten Kotawaringin Timur (Kotim) merupakan salah satu kabupaten yang memiliki kontribusi PDRB terbesar di Provinsi Kalimantan Tengah sebesar $17.54 \%$ terhadap PDRB total provinsi (BPS 2016). Pada tahun 2002 Kabupaten Kotim mengalami pemekaran menjadi Kabupaten Kotim, Seruyan dan Katingan. Setelah hampir 15 tahun Kabupaten Seruyan dan Katingan memisahkan diri dari Kabupaten Kotim serta telah tumbuh mandiri menjadi kabupaten yang berdaulat, ternyata isu disparitas atau ketimpangan pembangunan wilayah ini tetap masih ada.

Selain aspek produktivitas, faktor lain yang disinyalir menjadi penyebab ketimpangan pembangunan antar wilayah di kabupaten - kabupaten tersebut adalah aspek sumber daya antara lain rasio penguasaan tanah dan rasio infrastruktur. Pada kabupaten/ kota induk, kondisi sarana prasarana infrastruktur relatif lebih baik dibandingkan kabupaten pemekarannya. Sedangkan rasio penguasaan tanah (property tenurial) tercermin dari banyaknya (luas) perkebunan besar yang berada di wilayah tersebut sehingga berdampak mengurangi penguasaan lahan oleh masyarakat lokal. Perkembangan perkebunan skala besar sudah umum mengakibatkan pembatasan akses masyarakat ke sumberdaya agraria sehingga berakibat pada konfilik kepentingan antara investor dan masyarakat lokal 
(Soetarto et al. 2001). Lebih lanjut lagi Soetarto et al. (2007) menegaskan bahwa perbedaan akses terhadap sumberdaya agraria tersebut dapat menimbulkan permasalahan ketimpangan struktur agraria yang pada akhirnya akan mendatangkan konflik pertanahan antara masyarakat dengan perusahaan atau pemerintah sehingga menggangu kestabilan pembangunan. Menurut data Kantor Wilayah BPN Provinsi Kalimantan Tengah rasio (luas) Hak Guna Usaha (HGU) terbesar berada di Kabupaten Kotawaringin Timur (Kotim) dan sekitarnya. Dari aspek historis , menurut undang - undang nomor 5 tahun 2002 Kabupaten Kotim berubah yang semula satu kabupaten menjadi tiga kabupaten, yaitu Kabupaten Kotim sebagai kabupaten induk dan Kabupaten Seruyan dan Katingan sebagai kabupaten pemekarannya menjadi perhatian tersendiri untuk dapat di kaji lebih dalam lagi perihal perkembangan dan pembangunan wilayahnya. Berdasarkan uraian tersebut diatas maka ditetapkan tujuan dari penelitian ini adalah: menganalisis trend ketimpangan pembangunan regional di provinsi Kalteng dan faktor yang mempengaruhinya, menganalisis hirarki perkembangan wilayah di Kabupaten Kotim dan pemekarannya, menganalisis ketimpangan pembangunan pada Kabupaten Kotim dan pemekarannya serta faktor yang berpengaruh menggunakan Geographical Weighted Regression (GWR) dan menyusun rencana arahan dan kebijakan pengembangan wilayah di Kabupaten Kotim dan pemekarannya.

\section{METODE}

Penelitian ini dilaksanakan pada bulan Juli hingga bulan November 2017 di Provinsi Kalimantan Tengah dan dikaji lebih mendalam pada Kabupaten Kotim (induk), Katingan dan Seruyan (pemekaran). Letak geografis wilayah Provinsi Kalimantan Tengah adalah 0045’ Lintang Utara - 3030’ Lintang Selatan dan 110045’ - 115051’ Bujur Timur.

\section{Jenis dan sumber data}

Jenis data yang digunakan dalam penelitian ini berupa data sekunder, antara lain data HGU tahun 2008 - 2016 dari Kanwil BPN Provinsi Kalimantan Tengah, data - data statistik tahun 2008 - 2016 diperoleh dari BPS berupa data PDRB (Produk Domestik Regional Bruto) atas dasar harga konstan, data PODES tahun 2008 dan 2014, jumlah penduduk, kepadatan penduduk, jumlah penduduk miskin, IPM (Indek Pembangunan Manusia), Pendapatan Asli Daerah (PAD), jumlah kelahiran, jumlah murid dan guru SD, SMP dan SMU, Jumlah penduduk sakit (diare, demam berdarah, malaria, campak, dan insfeksi saluran pernapasan) dan Peta Administrasi Kabupaten Kotim, Katingan dan Seruyan dari Bappeda Provinsi Kalimantan Tengah.

\section{Analisis Data}

\section{Analisis Ketimpangan Pembangunan Wilayah di Provinsi Kalimantan Tengah}

Tingkat ketimpangan pembangunan wilayah diukur dengan menggunakan Indeks Williamson. Indeks ini menggunakan nilai PDRB per kapita pada tiap kabupaten. Indeks Williamson akan menghasilkan indeks yang lebih besar atau sama dengan nol. Jika Yi = Y maka akan menghasilkan nilai indeks $=0$, yang berarti tidak ada ketimpangan ekonomi antar daerah. Indeks lebih besar dari nol menunjukan adanya ketimpangan ekonomi antar daerah, dimana semakin lebih besar dari nilai 1 maka dapat diidentifikasi tingkat ketimpangan wilayah semakin besar. Data yang digunakan adalah PDRB menurut harga konstan Kabupaten/ kota di Provinsi Kalimantan Tengah tahun 2008 - 2016. 


$$
\mathbf{I W}=\sqrt{\sum \frac{(Y i-\overline{\mathrm{Y}})^{2} F_{i} / n}{\overline{\mathbf{Y}}}}
$$

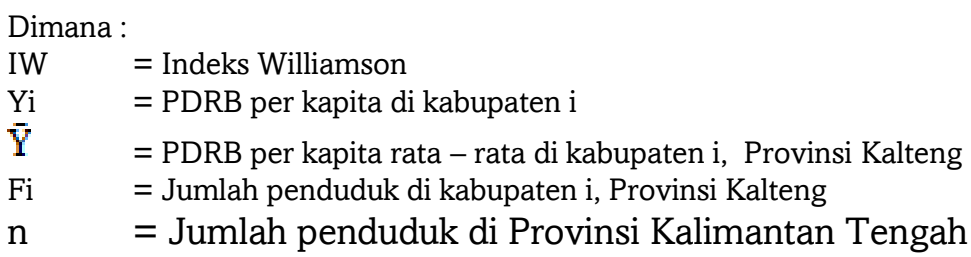

\section{Analisis Faktor - faktor yang mempengaruhi ketimpangan pembangunan wilayah}

Untuk mengetahui faktor - faktor ketimpangan pembangunan wilayah digunakan dua analisis, yaitu analisis regresi berganda data panel dan Geographically Weighted Regression (GWR). Analisis regresi data panel digunakan untuk mengetahui faktor - faktor yang mempengaruhi ketimpangan pembangunan wilayah secara regional. Variabel dependent yang digunakan dalam analisis regresi berganda adalah Indeks Williamson sedangkan sumber - sumber ketimpangan pembangunan wilayah digunakan sebagai variabel independent antara lain rasio infrastruktur yang ditunjukan dengan nilai indek perkembangan kabupaten atau IPK (Mopangga 2011; Rana 2017); ;indeks pembangunan manusia (IPM) dan PDRB Perkapita (Syahrial et al. 2015); kepadatan Penduduk atau KP; jumlah penduduk miskin atau PMIS (Ginting 2015); Pendapatan Asli Daerah atau PAD (Nurhuda et al.2013; Aprianoor dan Muktiali 2015); pertumbuhan jumlah penduduk (Barika 2012) dan rasio luas HGU atau RHGU. Dalam model regresi data panel untuk memilih teknik estimasi yang sesuai diperlukan uji Hausman. Jika probabilitas sama dengan nol maka teknik estimasi yang dipilih model FEM (Fix Effect Model), apabila tidak sama dengan nol maka dipilih model REM (Random Effect Model). Menurut Gujarati dan Porter (2009) jika teknik estimasi yang dipilih menggunakaan REM maka tidak perlu dilakukan asumsi klasik. Namun demikian, cukup banyak literatur yang menyatakan bahwa pada pendekatan REM yang diuji, cukup pada asumsi multikolineritas dan heteroskedasitas saja. Oleh karena itu, pada penelitian ini hanya dua asumsi klasik saja yang diujikan, yaitu asumsi multikolineritas dan heteroskedasitas. Metode ini mengestimasi data panel dengan menghitung error dari model regresi dengan metode Generalized Least Square (GLS) (Sillahi et al. 2014) dengan persamaan sebagai berikut:

Dimana:

$$
Y_{i t}=\beta_{o}+\beta_{\mathrm{j}} X_{i t}^{j}+\varepsilon_{i t} ; \varepsilon_{i t}=V_{t}+W_{i t}
$$

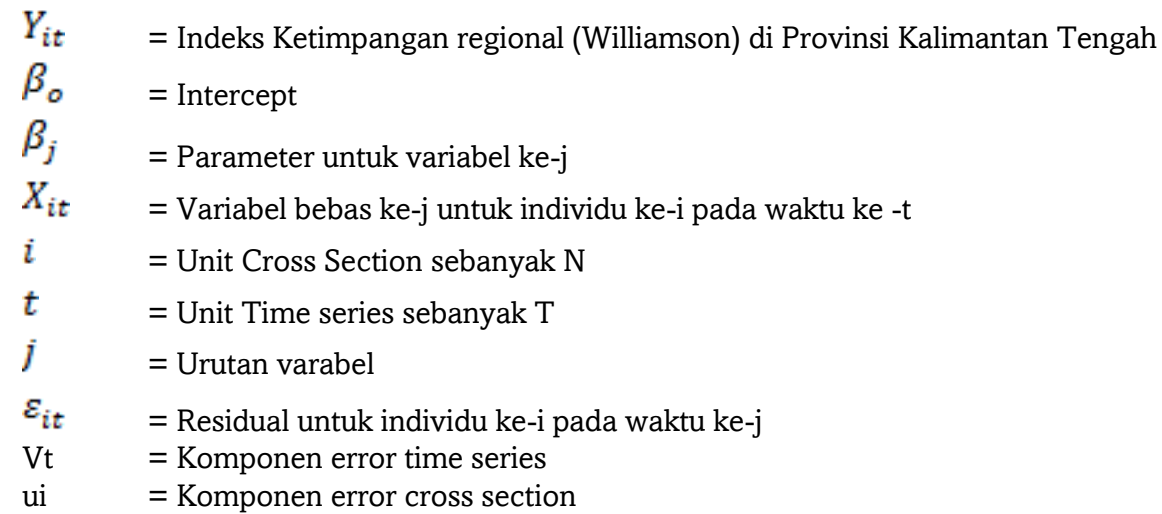


Wit $\quad=$ Komponen error gabungan

Dari delapan variabel tersebut dapat disusun suatu fungsi persamaan non linear yakni; $Y i t=\beta_{o}+\beta_{1} x_{1 i t}+\beta_{2} x_{2 \mathrm{it}}+\beta_{3} x_{3 \mathrm{it}}+\beta_{4} x_{4 \mathrm{it}}+\beta_{5} x_{5 \mathrm{it}}+\beta_{6} x_{6 \mathrm{it}}+\beta_{7} x_{7 \mathrm{it}}+\beta_{8} x_{8 \mathrm{it}}+\varepsilon_{i \mathrm{t}}$

Dimana:

$\mathrm{Y} \quad=$ Indeks Ketimpangan regional di Provinsi Kalimantan Tengah

Bo $\quad=$ Konstanta

$\beta_{1_{1} \ldots} \quad=$ Koefisien Regresi

$x_{\text {lit }}=$ Rasio HGU per kabupaten (RHGU) pada kabupaten i dan tahun $\mathrm{t}$

$x_{2 i t}=$ Indeks perkembangan wilayah kabupaten (IPK) pada kabupaten $\mathrm{i}$ dan tahun $\mathrm{t}$

$x_{3 i t}=$ Indeks Pembangunan Manusia (IPM) pada kabupaten i dan tahun $\mathrm{t}$

$x_{4 i t}=$ PDRB Konstan perkapita (PDRBP) pada kabupaten i dan tahun $\mathrm{t}$

$x_{\text {5it }}=$ Kepadatan Penduduk(KP) pada kabupaten i dan tahun $\mathrm{t}$

$x_{\text {6it }}=$ Jumlah Penduduk Miskin (PMIS) pada kabupaten i dan tahun $\mathrm{t}$

$x_{7 i t}=$ Pendapatan Asli Daerah (PAD) pada kabupaten i dan tahun $\mathrm{t}$

$x_{\text {Bit }}=$ Jumlah Penduduk $($ PEN) pada kabupaten i dan tahun $\mathrm{t}$

$\varepsilon \quad=$ Residual

Sedangkan analisis GWR dapat digunakan sebagai alat untuk mengeksplorasi variasi spasial terhadap hubungan antara variabel dependent dengan independent sehingga mampu menghasilkan visualisasi dan satu set regresi yang bersifat lokal (Pravitasari et al. 2015) atau regresi yang diboboti secara geografis (Rahmawati dan Djuraidah 2011). Analisis ini nantinya digunakan untuk menampilkan regresi spasial secara lokal berdasarkan faktor - faktor signifikan dari analisis regresi berganda. Secara umum formula GWR sebagai berikut ;

Keterangan:

$$
Y_{j}=\beta_{0}\left(U_{j}, V_{j}\right)+\sum_{i=1}^{p} \beta_{i}\left(U_{j}, V_{j}\right) X_{i j}+\varepsilon_{j}
$$

$$
\begin{aligned}
& Y_{j} \quad=\text { Indeks Perkembangan Kecamatan } \\
& \mathrm{Xij} \quad=\text { Variabel sumber }- \text { sumber ketimpangan } \\
& \mathrm{Xi} \quad=\text { lokasi } \mathrm{j} \\
& \beta_{0}\left(U_{j}, V_{j}\right) \quad=\text { Koefisien Regresi untuk variabel Xij di lokasi } \mathrm{j}
\end{aligned}
$$

jika nilai parameter regresi konstan pada tiap - tiap wilayah geografis, maka model GWR adalah model global. Artinya tiap-tiap wilayah geografis mempunyai model yang sama. Hal ini merupakan kasus spesial dari GWR. Selain menghasilkan estimasi parameter lokal disetiap lokasi geografis, GWR juga menghasilkan versi lokal untuk seluruh standard regression pada seluruh lokasi geografis misalnya ukuran goodness of fit. Hal ini dapat memberikan informasi pada pemahaman aplikasi dari model dan untuk penelitian lebih lanjut apakah diperlukan penambahan variabel independen pada model GWR. Hal yang penting lainnya model GWR tidak memerlukan titik dimana data diambil untuk mengestimasi parameter lokal. Jadi estimasi dari parameter dapat didapat dari semua lokasi geografis.

Selain itu peran pembobot pada model GWR sangat penting karena nilai pembobot ini mewakili letak data observasi satu dengan lainnya (Atikah 2014). Pembobot spasial akan menjelaskan letak lokasi pengamatan satu terhadap lainnya. Skema pembobotan spasial pada GWR dapat menggunakan beberapa metode yang berbeda, salah satu metode 
pembobotan yang biasa digunakan adalah kernel Gaussian dan fungsi pembobotan bisquare (Fotheringham et al. 2002; Bocci et al. 2006 Dalam atikah 2014). Fungsi Gaussian untuk menghitung titik ke-n yang terdekat sebagaimana yang digunakan dalam penelitian ini adalah

$$
W_{i j}=\exp \left[-\frac{\left(d_{i j} / b\right)^{2}}{2}\right]
$$

Dengan :

$\mathrm{j} \quad=$ salah satu titik ke-n yang terdekat dari titik $\mathrm{ke}-\mathrm{i}$

$\mathrm{b} \quad=$ jarak titik ke $-\mathrm{n}$ yang terdekat

dij $\quad=$ merupakan jarak Euclidean $\sqrt{\left(U_{i}-U_{j}\right)^{2}+\left(V_{i}-V_{j}\right)^{2}}$

Pemilihan nilai bandwidth optimum perlu dilakukan karena dapat mempengaruhi hasil penduga pada model. Metode yang dapat digunakan untuk menentukan nilai bandwidth yang optimum adalah dengan meminimumkan nilai Cross Validation (CV). Formula CV adalah sebagai berikut (Fotheringham et al., 2002).

$$
C V=\sum_{i=1}^{n}\left[y_{i}-\breve{y}_{\neq i}(b)\right]
$$

Dengan $\breve{y}_{\neq i}$ adalah nilai dugaan $y_{i}$ pada pengamatan lokasi ke-i dengan bandwith tertentu dihilangkan. Oleh karena data PDRB per kecamatan dan IPM pada level kecamatan tidak tersedia maka penilaian ketimpangan pembangunan didekati dengan indeks perkembangan kecamatan (IPK), sedangkan data IPM didekati dengan nilai IPSDM atau indeks potensi sumber daya manusia. IPSDM diperoleh dari penjumlahan komponen - komponen sosial dan ekonomi penyusun IPM dengan modifikasi antara lain rasio tingkat pekerjaan per 1000 penduduk, rasio hidup per 1000 penduduk, rasio murid dan guru per 1000 penduduk, rasio konsumsi perkapita dan sebagai pembobot menggunakan rasio kesakitan penduduk per 1000 penduduk. Komponen - komponen tersebut antara lain mengacu pada PP 6 Tahun 2008 tentang pedoman evaluasi penyelenggaraan pemerintah daerah. Indek total atau nilai IPSDM diperoleh dengan menggunakan persamaan sebagai berikut

$$
\begin{aligned}
& \text { IPSDM = (IRpb }+ \text { IRhh }+I R m g+I R k p)-I R s p \\
& \text { Dimana; } \\
& \begin{array}{ll}
\text { IPSDM } & \text { Indek Potensi Sumber Daya Manusia } \\
\text { Irpb } & =\text { Indek penduduk bekerja } \\
\text { Irhh } & =\text { Indek harapan hidup } \\
\text { Irmg } & =\text { Indek murid dan guru } \\
\text { Irkp } & =\text { Indek konsumsi perkapita } \\
\text { Irsp } & =\text { Indek kesakitan penduduk }
\end{array}
\end{aligned}
$$

\section{Penyusunan rencana arahan dan kebijakan pengembangan wilayah}

Penyusunan arahan dan kebijakan dilakukan secara deskriptif berdasarkan hasil kajian analisis ketimpangan pembangunan wilayah beserta faktor - faktor yang mempengaruhinya, analisis hirarki wilayah, dan faktor yang berpengaruh dalam perkembangan wilayah di level kecamatan menurut hasil GWR. Selanjutnya, dilakukan integrasi terhadap Rencana Tata Ruang Wilayah (RTRW) Kabupaten Kotim, Seruyan dan Katingan sehingga menghasilkan arahan dan kebijakan terhadap perkembangan wilayah. 


\section{HASIL DAN PEMBAHASAN}

\section{Hasil Analisis Trend Ketimpangan Pembangunan Wilayah}

Tingkat ketimpangan pembangunan antar kabupaten di Provinsi Kalteng pada periode tahun 2008 - 2016 ditunjukan dengan nilai Indeks Williamson (IW). Jika nilai indeks semakin mendekati nol maka tingkat ketimpangan pembangunan antar wilayah semakin kecil, begitu pula sebaliknya. Berdasaran hasil perhitungan, diperoleh rata - rata ketimpangan wilayah di Provinsi Kalteng sebesar 0.22. Angka ini menunjukan bahwa tingkat ketimpangan pembangunan di Provinsi Kalteng tergolong rendah. Perkembangan nilai IW periode 2008 - 2016 di Provinsi Kalimantan Tengah secara jelas dapat dilihat pada Gambar 1.

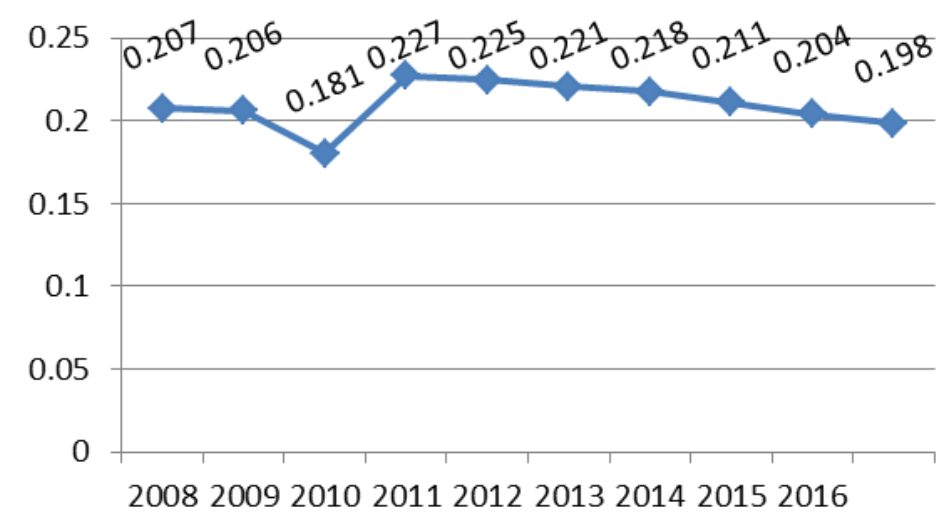

\section{Gambar 1 Trend Ketimpangan Wilayah (Nilai IW)}

Gambar 1 menunjukkan bahwa secara umum perkembangan ketimpangan pembangunan di Provinsi Kalteng masih fluktuatif namun cenderung mengalami penurunan. Hal ini mengindikasikan tingkat pertumbuhan ekonomi yang mulai merata di wilayah Provinsi Kalteng. Secara lengkap dapat dilihat pada Tabel 1.

Tabel 1 Nilai IW Kabupaten di Provinsi Kalimantan Tengah Tahun 2008-2016

\begin{tabular}{|c|c|c|c|c|c|c|c|}
\hline \multirow[t]{2}{*}{ No } & \multirow[t]{2}{*}{ Kabupaten } & \multicolumn{3}{|c|}{ Nilai Indek Williamson } & & & \multirow[t]{2}{*}{ Rerata } \\
\hline & & 2008 & 2010 & 2012 & 2014 & 2016 & \\
\hline 1 & Kapuas & 0.82 & 3.41 & 3.47 & 3.39 & 3.16 & 2.80 \\
\hline 2 & Pulang Pisau & 0.53 & 2.51 & 2.57 & 2.51 & 2.45 & 2.08 \\
\hline 3 & Barito Utara & 0.01 & 1.84 & 2.32 & 2.71 & 2.94 & 1.93 \\
\hline 4 & Murung Raya & 0.21 & 1.66 & 1.88 & 1.98 & 2.13 & 1.54 \\
\hline 5 & Katingan & 0.05 & 1.84 & 1.86 & 1.92 & 1.92 & 1.48 \\
\hline 6 & Gunung Mas & 0.25 & 1.44 & 1.57 & 1.68 & 1.72 & 1.31 \\
\hline 7 & Sukamara & 0.72 & 1.44 & 1.34 & 1.25 & 1.16 & 1.17 \\
\hline 8 & Kotawaringin Barat & 0.75 & 1.14 & 1.18 & 1.22 & 1.21 & 1.07 \\
\hline 9 & Barito Selatan & 0.23 & 1.24 & 1.22 & 1.26 & 1.27 & 1.01 \\
\hline 10 & Barito Timur & 0.25 & 1.22 & 1.22 & 1.19 & 1.04 & 0.97 \\
\hline 11 & Lamandau & 0.17 & 1.00 & 1.01 & 1.08 & 1.16 & 0.85 \\
\hline 12 & Seruyan & 0.49 & 0.07 & 0.43 & 0.85 & 1.40 & 0.60 \\
\hline 13 & Kotawaringin Timur & 0.12 & 0.83 & 0.38 & 0.17 & 0.22 & 0.29 \\
\hline 14 & Palangka Raya & 0.16 & 0.16 & 0.19 & 0.21 & 0.20 & 0.19 \\
\hline
\end{tabular}


Berdasarkan Tabel 1 tingkat ketimpangan pembangunan wilayah tertinggia di Provinsi Kalteng yaitu Kabupaten Kapuas, sedangkan ketimpangan terendah yaitu Kota Palangkaraya. Kabupaten Kotim termasuk pada kabupaten dengan tingkat ketimpangan terendah kedua dengan rata - rata nilai indeks 0.29 sementara daerah pemekaraanya Kabupaten Seruyan dan Katingan memiliki ketimpangan pembangunan yang tinggi dengan rata - rata indeks ketimpangan 0.6 dan 1.7. Dengan demikian, Kabupaten Katingan dan Seruyan sebagai kabupaten pemekaran masih belum menyamai pemerataan pembangunan di Kabupaten Kotim sebagai kabupaten induknya, meski dari nilai rata - rata ketimpangan wilayah periode tahun 2008 - 2016 Kabupaten Seruyan berada tepat dibawah Kabupaten Kotim.

\section{Hasil analisis faktor yang mempengaruhi ketimpangan pembangunan wilayah di Provinsi Kalimantan Tengah}

Dalam rangka untuk mengidentifikasi sumber - sumber ketimpangan pembangunan di Provinsi Kalteng maka digunakan analisis regresi data panel yang terdiri dari data cross section berupa 13 kabupaten dan 1 kota di Provinsi Kalteng serta data time series dari tahun 2008 - 2016. Nilai ketimpangan antar kabupaten digunakan sebagai data dependent, sedangkan data independent yang digunakan berupa data RHGU (Rasio luas HGU per Kabupaten), IPK (Indek Perkembangan Kabupaten), IPM (Indek Perkembangan Manusia), PDRBP (PDRB Perkapita), KP (Kepadatan Penduduk), PMIS (Penduduk Miskin), PAD (Pendapatan Asli Daerah) dan PEND (jumlah Penduduk). Berdasarkan Hasil yang diperoleh dari dari Uji Hausman pada taraf nyata $5 \%$ menyatakan bahwa teknik estimasi yang paling baik digunakan untuk menggambarkan ketimpangan wilayah adalah model REM (Random Effect Model), hal ini dibuktikan dengan nilai uji hausman sebesar 0.5420 yang berarti lebih dari $0.05(\alpha=5 \%)$. Hasil uji asumsi klasik berupa multikolineritas dan heteroskedasitas diperoleh bahwa model ini bebas dari masalah heteroskedasitas namun masih terdapat masalah multikolineritas. Untuk mengatasi permasalahan multikolineritas maka digunakanlah metode SUR (Seemingly Unrelated Regression) sehingga dihasilkan galat yang lebih kecil (Widyaningsih et al, 2014).

Menurut uji $t$ (t Stat) pada taraf nyata 5\% diperoleh faktor - faktor yang signifikan dalam mempanguruhi tingkat ketimpangan di Provinsi Kalteng antara lain RHGU, IPK, PMIS, PEND, dan IPM. Variabel lain seperti KP, PDRBP dan PAD tidak signifikan sebagai faktor yang mempengaruhi ketimpangan. Nilai R-sq (R square) yang dihasilkan dari model ini cukup tinggi, yaitu 0.8014 atau $80.14 \%$ yang artinya $80.14 \%$ model ini mampu menjelaskan tingkat ketimpangan pembangunan di Provinsi Kalteng oleh faktor RHGU, IPK, IPM, KP,PMIS, PAD, dan PEND meskipun sisanya sebesar $19.86 \%$ dijelaskan oleh faktor lain diluar model ini. Apabila nilai R2 semakin mendekati 1, maka model dikatakan semakin fit, namun pengertian fit dalam hal ini tidak berarti model yang memiliki R2 yang sangat kecil tidak berguna sama sekali (Firdaus 2011).

Tabel 2 Hasil Regresi Berganda Unbalanced Panel

\begin{tabular}{|c|c|c|c|}
\hline IW & Coef & $\mathrm{P}>|\mathrm{z}|$ & \\
\hline RHGU & -6.0424 & $0.000^{\star}$ & $\mathrm{R}-\mathrm{sq}=0.8014$ \\
\hline IPK & 0.9326 & $0.013^{\star}$ & Hausman: \\
\hline $\mathrm{KP}$ & -0.3046 & 0.120 & Prob $>$ chi2 $=0.5420$ \\
\hline PDRBP & -0.0008 & 0.939 & Breusch-Pagan / Cook- \\
\hline PMIS & -0.8934 & $0.001^{*}$ & Weisberg test \\
\hline PEND & 0.0000 & $0.007^{*}$ & heteroskedasticity \\
\hline PAD & -0.1334 & 0.523 & Prob $>$ chi $2=0.5927$ \\
\hline IPM & -0.1759 & $0.000^{\star}$ & \\
\hline Cons & 12.6402 & & \\
\hline
\end{tabular}


*Signifikan $\alpha=5 \%$

Sumber: Data Olahan, 2017

Berdasarkan hasil analisis regresi dapat dijelaskan bahwa faktor - faktor seperti RHGU, PDRBP, PMIS, dan IPM berkorelasi negatif sedangkan IPK dan PEND berkorelasi positif terhadap tingkat ketimpangan. Artinya, semakin besar RHGU, PDRBP, PMIS, dan IPM di suatu wilayah maka tingkat ketimpangan suatu wilayah tersebut akan semakin berkurang. Sedangkan faktor IPK dan PEND pada provinsi Kalteng berlaku sebaliknya. Nilai koefisien yang tinggi pada faktor RHGU mengindikasikan bahwa pengaruh faktor ini terhadap ketimpangan pembangunan wilayah cukup tinggi sehingga faktor ini menjadi yang paling dominan.

\section{Hasil Analisis Perkembangan Wilayah di Kabupaten Kotim dan Pemekarannya}

Analisis skalogram selain dapat digunakan untuk mengetahui hirarki atau perkembangan suatu wilayah juga dapat digunakan untuk mengetahui ketimpangan antar wilayah (Soares et al. 2017). Kecamatan yang masuk kategori hirarki 1 disebut juga kecamatan yang paling maju, dicirikan dengan nilai indek perkembangan kecamatan (IPK) paling tinggi dengan jumlah sarana prasarana yang memadai dan jarak yang dekat dengan fasilitas pelayanan. Hirarki 2 merupakan kecamatan dengan tingkat perkembangan wilayah sedang, dicirikan dengan jumlah sarana prasarana yang lebih sedikit dibanding dengan hirarki 1 dan jarak antar fasilitas yang lebih jauh dari hirarki 1 . Hirarki 3 termasuk kategori kecamatan yang kurang maju, dicirikan dengan jumlah sarana prasarana yang kurang memadai dan jarak antar fasilitas dengan masing - masing kecamatan jauh untuk dijangkau daripada hirarki 1 dan 2. Konsep perkembangan wilayah didasarkan pada rasio jumlah dan jenis sarana prasarana terhadap jarak. Perbandingan hirarki wilayah berdasarkan nilai IPK dapat dilihat pada Gambar 2.

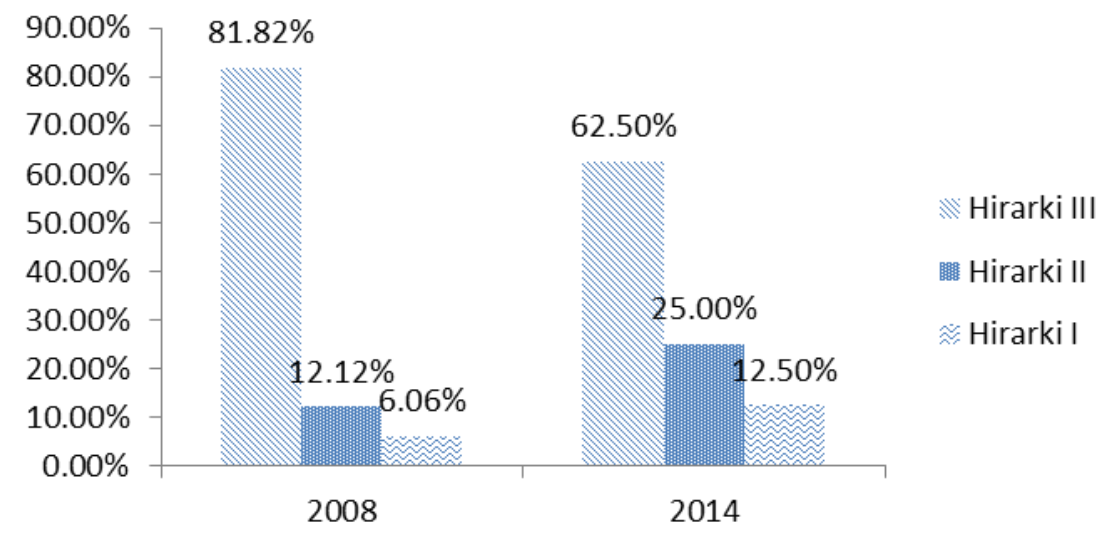

\section{Gambar 2 Perbandingan Hirarki Wilayah Tahun 2008 dan 2014}

Berdasarkan Gambar 2 dapat dilihat bahwa perkembangan wilayah di Kabupaten Kotim dan pemekarannya periode 2008 - 2014 mengalami perkembangan wilayah meskipun secara umum masih didominasi oleh wilayah kecamatan yang relatif tertinggal. Hal ini ditandai dengan jumlah hirarki 3 yang masih mendominasi keseluruhan wilayah kecamatan pada tahun 2014 atau sebesar 62,5 persen dari jumlah kecamatan yang ada. 
Kondisi ini selain karena adanya pemekaran kecamatan juga dipengaruhi oleh peningkatan jumlah penduduk yang tidak diimbangi dengan fasilitas pelayanan umum. Disisi lain, faktor RHGU sebagai faktor dominan yang berperan dalam menggerakkan pertumbuhan ekonomi juga disinyalir sebagai penyebab wilayah - wilayah yang berada dilokasi HGU tersebut menjadi tertekan dan terbatas dalam mengembangkan wilayahnya. Kondisi ini terjadi karena penguasaan HGU yang sangat luas tersebut telah merenggut dan menyita sebagaian besar dari ruang wilayah tersebut sehingga akses terhadap masyarat terhadap sumber agraria menjadi terbatas atau bahkan tertutup (Soetarto et al. 2007). Jika dibiarkan, bukan tidak mungkin akan memicu terjadinya permasalahan lain, seperti kemiskinan dan konflik agraria.

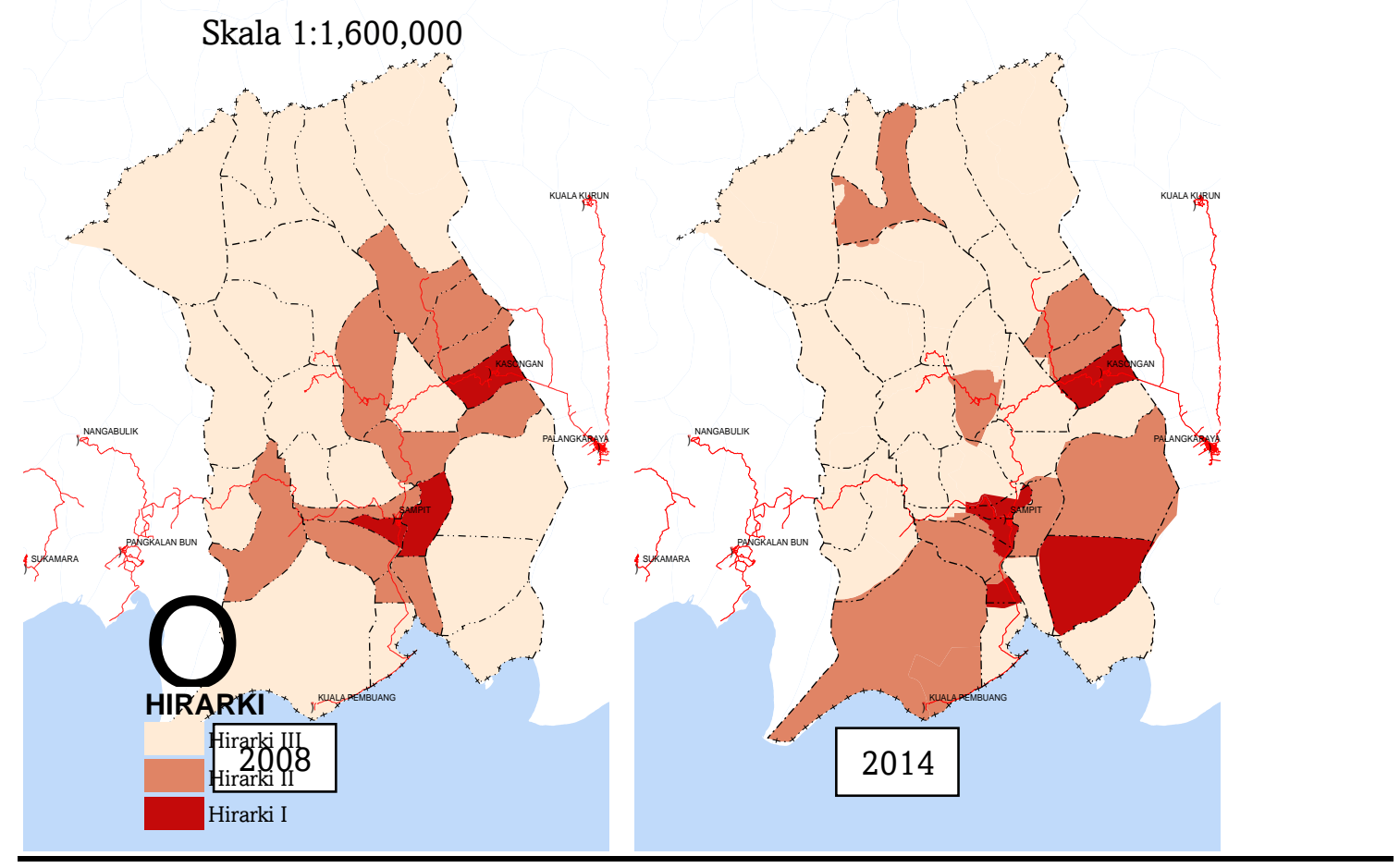

Gambar 3 Pola Sebaran Hirarki Wilayah Penelitian

Berdasarkan Gambar 3 dapat dilihat pula perkembangan pola sebaran hirarki wilayah antara tahun 2008 dan 2014. Pada tahun 2008 perkembangan wilayah cenderung di wilayah tengah atau pada wilayah kecamatan yang menjadi ibukota kabupaten. Sedangkan pada tahun 2014 perkembangan wilayah mengalami kecenderungan bergeser kearah selatan sehingga memicu ketimpangan pembangunan wilayah antara diutara dan selatan, yakni wilayah selatan relatif lebih maju dibandingkan dengan wilayah utara.

Hasil Analisis Faktor yang berpengaruh terhadap perkembangan wilayah di Kabupaten Kotim dan pemekarannya

Seperti yang sudah diketahui bahwa faktor - faktor yang mempengaruhi ketimpangan wilayah di Propinsi Kalteng disebabkan oleh RHGU, IPK, PMIS, PEND, dan IPM. Namun, faktor - faktor tersebut berlaku secara global sehingga belum mampu menunjukkan pengaruhnya terhadap wilayah yang lebih mikro (kecamatan). Oleh karena itu, sumber - sumber ketimpangan pada level kabupaten tersebut akan di uji kembali menggunakan pendekatan GWR sehingga diperoleh faktor penyebab ketimpangan wilayah secara lokal atau lebih spesifik pada wilayah kecamatan tertentu. Mengingat data PDRB 
tingkat kecamatan tidak tersedia, maka untuk mengetahui ketimpangan wilayah level kecamatan menggunakan IPK atau nilai hirarki wilayah pada masing - masing kecamatan. Data IPM pada level kecamatan juga tidak tersedia sehingga penulis menggunakan indeks potensi sumber daya manusia (IPSDM) yang dihasilkan dari integrasi komponen sosial dan ekonomi IPM. Nilai IPK ini selanjutnya digunakan sebagai variabel dependent nya sedangkan variabel independent nya antara lain RHGU, PMIS, PEND dan IPSDM. Untuk lebih jelasnya, sebaran spasial hasil GWR dapat dilihat pada Gambar 4 dan Gambar 5.

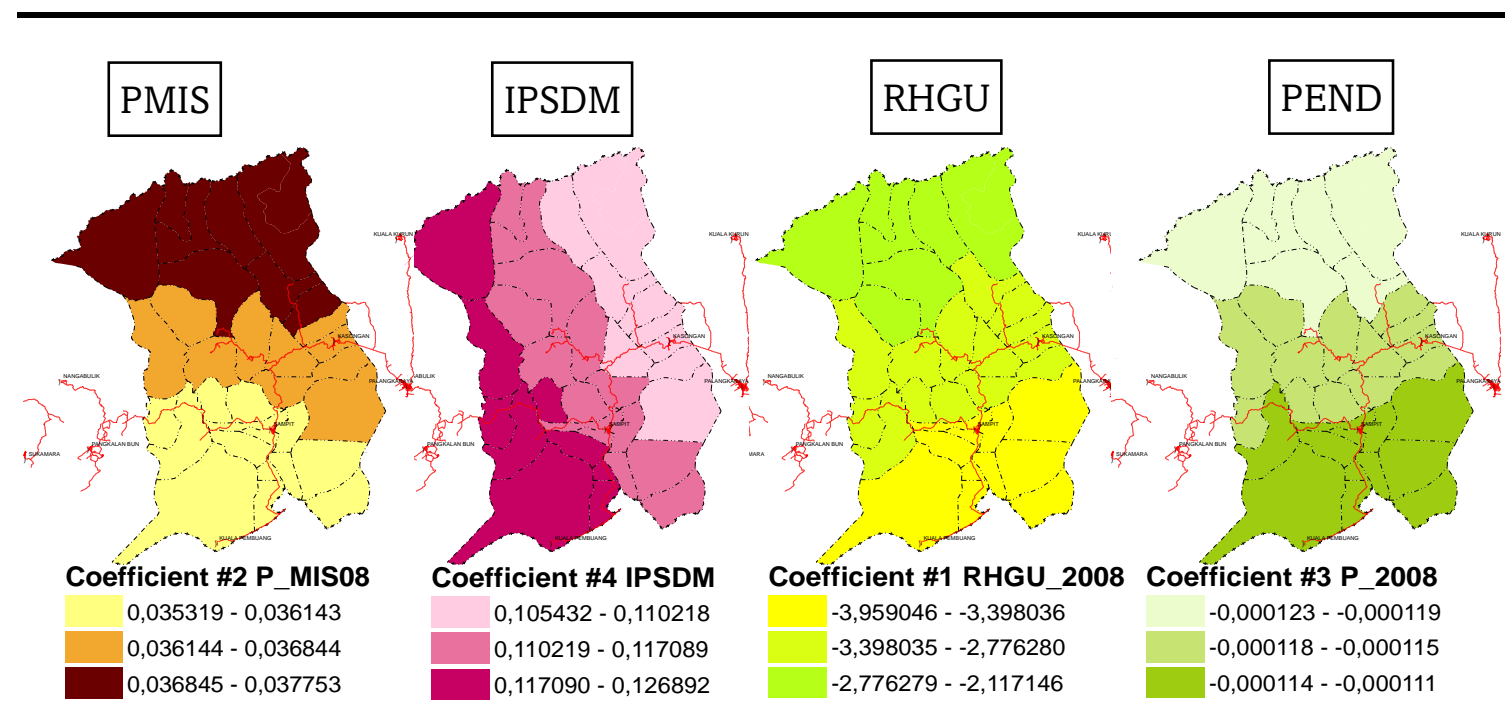

Gambar 4 Hasil GWR faktor penyebab ketimpangan Tahun 2008
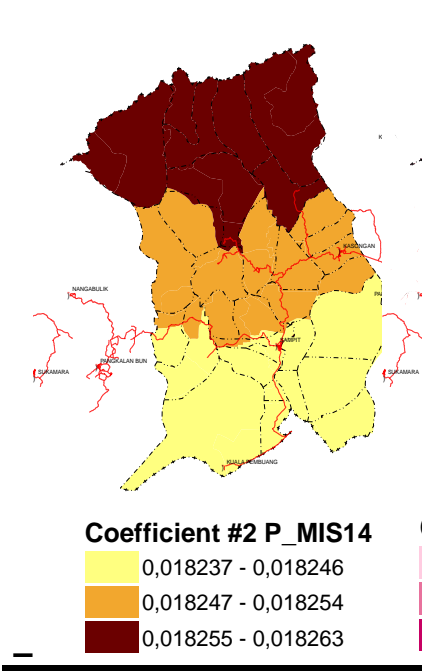

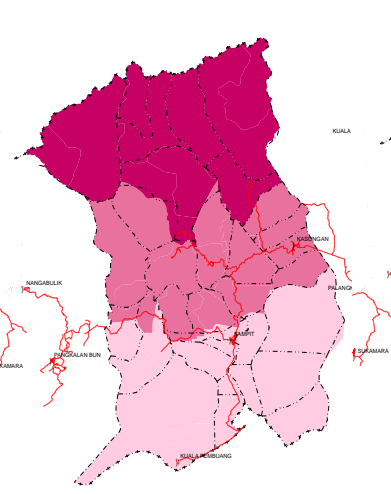

Coefficient \#4 IPSDM_14 $3,085005-3,085707$ $3,085708-3,086340$ $3,086341-3,087032$

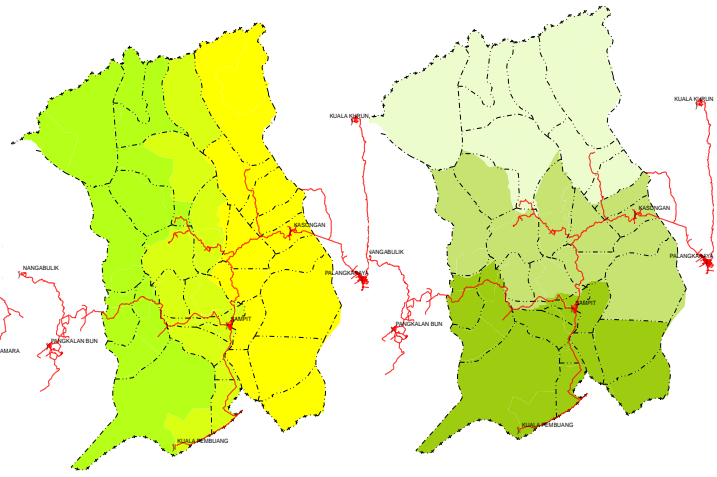

Coefficient \#1 RHGU_2014 $-12,042463--12,039482$ $-12,039481--12,036440$ $-12,036439--12,031285$
Coefficient \#3 P_2014 0,000089

0,000090

$0,000091-0,000090$

Gambar 5 Hasil GWR faktor penyebab ketimpangan Tahun 2014

Menurut hasil GWR, pengaruh tiap variabel yang digunakan hampir sama disemua lokasi penelitian pada Kabupaten Kotim, Seruyan dan Katingan dengan urutan kontribusi RHGU, IPSDM, PMIS dan PEND terhadap perkembangan wilayah tidak berubah. RHGU 
dan IPSDM masih menjadi faktor yang paling berpengaruh terhadap perkembangan wilayah. Bahkan pada tahun 2014, kontribusi pengaruhnya semakin meningkat. Berdasarkan Gambar 4 dan Gambar 5 dapat dilihat bahwa nilai koefisien RHGU meningkat menjadi -12 pada tahun 2014 dari -3 pada tahun 2008, sedangkan IPSDM meningkat dari 0.1 menjadi 3. Hal ini mengindikasikan pengaruh RHGU juga dominan dalam mempengaruhi perkembangan wilayah periode 2008 - 2014. RHGU menjadi faktor yang paling besar pengaruhnya dibandingkan faktor lain terhadap perkembangan wilayah. Dengan kata lain, menurut hasil GWR dapat diartikan bahwa ketika terjadi peningkatan 1 persen pada rasio penguasaan HGU (RHGU), maka tingkat perkembangan wilayah akan mengalami penurunan/ kemunduran wilayah sebesar 8 persen pada tahun 2008 dan 12 persen pada tahun 2014 di seluruh wilayah Kabupaten Kotim, Seruyan dan Katingan, ceteris paribus.

\section{Arahan rencana pengembangan dan kebijakan pengembangan wilayah}

Arah pengembangan wilayah disusun dengan mempertimbangkan faktor - faktor yang telah terbukti mempengaruhi tingkat ketimpangan wilayah baik dari level kabupaten maupun kecamatan. Hasil penelitian menunjukan faktor RHGU memiliki pengaruh yang paling besar baik dalam mempengaruhi tingkat ketimpangan dan perkembangan wilayah ditingkat kabupaten maupun kecamatan. Banyaknya perkebunan besar yang telah memiliki HGU menunjukan banyaknya pula kegiatan investasi ekonomi di wilayah Kabupaten Kotim dan pemekarannya. Namun, pengelolaan sumberdaya yang ada belum berpihak kepada masyarakat lokal sehingga justru membatasi akses masyarakat lokal terhadap sumber agraria. Menurut Soetarto (2004) sejak tahun 1960 Indonesia sebenarnya telah memiliki Undang - undang Pokok Agraria (UUPA) yang sangat populis dan berperan sebagai ruh dalam pembangunan namun pada kenyataannya politik pengelolaan sumber daya alam sampai saat ini masih didasarkan pada kepentingan kebutuhan investasi atau dengan kata lain sumberdaya alam dipandang serta dipahami dalam konteks economic sense dan belum dipahami sebagai ecological dan sustainable sense (termasuk dalam hal ini kelangsungan hidup komunitas lokal). Ini senada dengan hasil penelitian yang menunjukan bahwa tingkat ketimpangan wilayah regional yang meski rendah namun tingkat perkembangan wilayah justru semakin menurun pada level kecamatan di Kabupaten Kotim, Seruyan dan Katingan, terutama periode tahun 2008 - 2014. Dengan kata lain, faktor RHGU berperan besar dalam proses kemunduran wilayah atau tidak berkembang.

Oleh karena itu, diperlukan kebijakan seperti moratorium terhadap legalisasi penguasaan tanah melalui pemberian izin HGU di kawasan perkebunan dan urgensi pelaksanaan reforma agraria di kawasan perkebunan - perkebunan besar pemilik HGU sebagai upaya pemerataan ekonomi dan menekan ketimpangan (Soetarto 2004; Barus 2017) di wilayah Kabupaten Kotim, Seruyan dan Katingan. Disamping itu, peningkatan pembangunan infrastruktur fasilitas umum juga harus lebih intensif terutama pada wilayah kecamatan yang termasuk dalam kategori hirarki III pada masing - masing kabupaten untuk mencegah adanya kebocoran wilayah. Hal ini tentu juga harus dibarengi dengan upaya intensif dalam rangka meningkatkan potensi sumber daya manusianya.

\section{KESIMPULAN}

Secara umum Provinsi Kalimantan Tengah memiliki ketimpangan pembangunan wilayah yang rendah sehingga antar kabupaten/ kota hampir mengalami pembangunan wilayah yang merata dengan faktor - faktor yang mempengaruhinya antara lain Rasio HGU, Indeks Perkembangan Kabupaten, Jumlah Penduduk Miskin, Jumlah Penduduk dan IPM. Pembangunan wilayah pada level kecamatan di Kabupaten Kotawaringin Timur, Seruyan dan Katingan mengalami fluktuasi di kurun waktu 2008 - 2014 namun cenderung 
tetap. Pola spasial menunjukkan kecenderungan perkembangan wilayah terjadi ke wilayah selatan sehingga memicu terjadinya ketimpangan wilayah antara utara dan selatan. Hal ini menurut hasil GWR disebabkan oleh faktor rasio HGU. Rasio HGU berpengaruh di hampir seluruh wilayah tersebut dalam hal menyebabkan penurunan perkembangan wilayah. Penguasaan HGU yang sangat besar oleh beberapa perusahaan menyebabkan sebagian besar ruang wilayah tersita oleh aktivitas ruang didalam HGU itu sendiri sehingga wilayah menjadi tidak berkembang. Selain itu, peningkatan potensi sumber daya manusia dan pembangunan infrastruktur fasilitas umum pada wilayah ber hirarki rendah juga perlu untuk diwujudkan guna mencegah terjadinya kebocoran wilayah. Dengan demikian, kondisi ini mendorong urgensi reforma agraria di kawasan perkebunan.

\section{UCAPAN TERIMA KASIH}

Ucapan terima kasih disampaikan kepada Pusat Pembinaan dan Pendidikan Pelatihan Perencana Badan Perencanaan Pembangunan Nasional (Pusbindiklatren Bappenas) yang telah mendukung pendanaan penelitian ini, serta para pihak yang telah membantu dalam penelitian ini.

\section{DAFTAR PUSTAKA}

Aprianoor P dan Muktiali M. 2015. Kajian Ketimpangan wilayah di Provinsi Jawa Barat. Jurnal Teknik PWK UNDIP 4(4): 484-498

Barika.2012. Analisis Ketimpangan Pembangunan Wilayah Kabupaten/ Kota di Provinsi Bengkulu 2005-2009. Jurnal Trikonomika 4(3):1-11

Barus B. 2017. Reforma Agraria di Kawasan Perkebunan: Penentuan ukuran maksimum HGU. Di dalam: Seminar Menuju Konferensi Tenurial 2017, Reforma Agraria di Luar Kawasan Hutan: Peluang dan Tantangan; 2017 Okt 23-24; IPB ICC Bogor.

[BPS]Badan Pusat Statistik .2016. Provinsi Kalimantan Tengah dalam Angka. Diakses pada tanggal 7 Januari 2017 di https://www.kalteng.bps.go.id

Ginting AM. 2015. Pengaruh Ketimpangan Pembangunan Antarwilayah Terhadap Kemiskinan di Indonesia 2004 - 2013. Jurnal Kajian 20(1): 45-58

Firdaus M. 2011. Aplikasi Ekonometrika Untuk Data Panel dan Time Series. Bogor (ID): IPB Press

Gujarati DN dan Porter DC. 2009. Ekonometrika Dasar Ed ke-5. Erlangga: Jakarta

Mopangga, H. 2011. Analisis ketimpangan pembangunan dan pertumbuhan Ekonomi di Provinsi Gorontalo. Jurnal Trikonomika 10(1):40-51

Mohiuddin S dan Hashia H. 2012. Regional socio- economic disparities in the Kashmir Valley (India)- a geographical approach. Bulletin of Geography Socio Economic Series 1(18):85-98

Nurhuda R, Muluk MRK, Prasetyo WY. 2013. Analisis Ketimpangan Pembangunan (Studi di Provinsi Jawa Timur Tahun 2005 - 2011). Jurnal Administrasi Publik 1(4): 110-119.

Pravitasari AE, Saizen I, Tsutsumida N, Rustiadi E dan Pribadi DO. 2015. Local Spatially Dependent Driving Forces of Urban Expansion in an Emerging Asian Megacity: The Case of Greater Jakarta (Jabodetabek). International Journal of Sustainable Development 8 (1): 108-119.

Rahmawati R dan Djuraidah A. 2011. Analisis Geographically Weighted Regression (GWR) Dengan Pembobot Kernel Gaussian Untuk Data Kemiskinan. Prosiding Seminar Nasional Statistika Universitas Diponegoro [Internet]. [Prodi Statistika Fakultas MIPA]. Semarang (ID): 326-322 [diunduh pada 1 Mei 2017]. Tersedia pada: eprints.undip.ac.id/39119/1/5.GWR.pdf

Rana IA, Bhatti SS, dan Saqib SE. 2017. The spatial and temporal dynamics of infrastructure development disparity-from assesment to analyses. Journal Cities 63: 20-32.

Rustiadi E, Saefulhakim S, dan Panuju DR.2011. Perencanaan dan Pengembangan Wilayah. Jakarta (ID): Crespents Press dan Yayasan Pustaka Obor Indonesia.

Soares L, Rustiadi E dan Mulatsih S. 2017. Analisis Disparitas dan Interaksi Spasial di Timor Leste. Journal Of Regional Development Planning 1(1): 74-86

Soetarto E, Sitorus MTF dan Napiri MY.2001. Decentralisation of Administration, Policy Making and Forest Management in Ketapang District, West Kalimantan. CIFOR: Jakarta (ID) 
Soetarto E, Sihaloho M dan Purwandari H. 2007. Pemanfaatan Sumber - Sumber Agraria Lokal Dalam Mendukung Ekonomi Keluarga (Studi Kasus di Desa Mendiro, Kabupaten Ngawi, Propinsi Jawa Timur). Jurnal Transdisiplin Sosilogi, Komunikasi dan Ekologi Manusia 1(2): 271-282.

Soetarto E. 2004. Signifikasi reforma agraria sebagai dasar pembangunan pertanian tangguh menuju ketahanan pangan. Di dalam: Seminar tekanan penduduk, degradasi lingkungan dan ketahanan pangan [internet]; Badan BIMAS Ketahanan Pangan, Departemen Pertanian RI [waktu tidak diketahui]. Bogor (ID): IPB. 187-195; [diunduh 11 September 2017] tersedia http://mobile.repository.ipb.ac.id/handle/123456789/25396?show=full

Syahrial, Hakim DB \& Purnamadewi YL. 2015. Disparitas Regional Provinsi Sumatera Barat di Era Otonomi Daerah. Jurnal Tataloka 17(1): 53-63

Tambunan, TTH. 2003. Perekonomian Indonesia: Beberapa Masalah Penting. Jakarta (ID): Ghalia Indonesia

Widyaningsih, A., Susilawati, M., Sumarjana I W. 2014. Estimasi Model Seemingly Unrelated Regression (SUR) dengan metode Generalized Least Square (GLS). Jurnal Matematika 4(2): 102-110 